\title{
Transformational Leadership is Shaping the Research \& Development Culture of Pakistani Universities: A Case Analysis
}

\author{
HASSAN DAUD BUTT \\ Ph.D. Scholar, Department of Management Studies, Bahria University Islamabad. \\ Email: hdb4049@gmail.com
}

Dr. RIAZ AHMED

Senior Associate Professor, Department of Management Studies, Bahria University Islamabad. Email: riazutm@gmail.com

\author{
ISRAR AHMED \\ Student Advisor, Department of Business Studies, Bahria University Islamabad. \\ Email: israr.buic@bahria.edu.pk
}

\begin{abstract}
This research analyses 629 university leaders and investigates the effect of personality attributes and cross cultural experiences as predictors of dynamic cross cultural competencies in an research and developemnt setting. The study finds out and suggests that transformational leadership develops through work related and non-work related activities of cultural as well as personality characteristics.
\end{abstract}

Keywords: Transformational Leadership, Cross Culture, Personality Attributes, Global Leaders.

\section{Introduction}

The Pakistani government has set out on a way of monetary development by changing the nation wealth economy into an information-based economy. Training in the education sector is viewed as a significant piece of the advancement of human and scholarly capital. Human capital and academic capital are considered the basis of a viable information economy. Hence, the Pakistani government in its National Actional Plan 2013 - 2016 has placed more weight on expanding access to advanced education and preparing a mass of an exceptionally talented workforce. This important accomplishment has been achieved by setting up and widening the scope of educational organizations, including state-funded colleges, private colleges with affiliation of public and private universities that award degrees, non-degree specialized schools, and polytechnic institutes. Until this point in time, Pakistan has allocated budget of 350 billion rupees with the $90 \%$ yield rate (Islamabad 2013).Scholastic R\&D is also a key part of the national development framework, which has significantly achieved fundamental research outcomes, led by these national educational institutes (Aghion, Dewatripont et al. 2008).

Besides, the goal of the government is also to develop human skills and abilities in specific fields of science and innovation, (for example, atomic science, medication, and avionics innovation), which are considered strategic to the country. However, due to uncertain financial returns, private sector investment is naturally impossible to enter these fields; many governments allocate large amounts of funds to universities to grow these fundamental research fields. Numerous Universities have created different techniques to improve their research and development (R\&D) capacities. Higher Education Commission has granted huge sums of 
funds to the Excellence Programs for universities in order to boost progressively higher degree of research and development (Abd Razak 2009).

Research and development productivity indicators (such as peer surveys, distribution, and paper references) are important indicators for evaluating university rankings. Universities should also have to put gigantic efforts to improve their innovative work effectiveness and utilization of funds. Regardless of the need to give monetary help and physical foundation, universities additionally should assess Do they have the right R\&D culture? As can be seen from the official site, numerous Higher Education Institutes/Universities underline the significance of building up $\mathrm{R}$ and $\mathrm{D}$ culture. On examination of the $\mathrm{R}$ and $\mathrm{D}$ culture of Higher Education Institutes and different Universities, it is found that they are fundamentally progressing (Asmawi, Zakaria et al. 2013).

Other researches on Higher Education Universities innovative R\&D work culture has adopted a subjective methodology (Moss and Kubacki 2007, Tynan and Garbett 2007, Beerkens 2010). It is further found that, hierarchical culture is formed by authoritative pioneers (Sarros, Gray et al. 2002). Existing research explains that the transformative leadership initiative is a significant factor in supporting R\&D (Nemanich and Vera 2009). For this reason, this study will examine how the executive leadership administration style in Pakistani Higher Education Universities shapes the R\&D culture. Numerous past investigations have concentrated on the effect of a solitary chief (eg, CEO or senior supervisor) on hierarchical execution but the need to contemplate the aggregate impact of leadership at various levels is still unsearched (Hunter, Bedell-Avers et al. 2007). The fact levels the grounds that the research culture has strong relationship with leadership (Berson and Avolio 2004).

This research will concentrate on the aggregate senior and center supervisory crew of the Higher Education universities, which incorporates the Vice Chancelors and their administrators engaged with the key dynamics, for example, VCs, Directors, Deans and Head of Departments. In spite of the fact that we perceive that Vice Chancellors and Directors, additionally assume a significant job in scholarly R\&D ventures, they are not the focal point of this article. We accept that Deans and Head of Departments (HOD) have a more noteworthy state in leading the culture of $R \& D$ than group pioneers, the top level supervisors.

This exploratory investigation intends to accomplish two research objectives. The main objective is to decide the R\&D social model of Pakistani universities. The subsequent objective is to research the connection between transformative leadership initiative and $\mathrm{R}$ and $\mathrm{D}$ culture in Pakistani Higher Education Institutes/University. This examination is significant in light of the fact that it gives Higher Education Institutes/University a more profound comprehension of the potential authoritative culture that may advance or impede $\mathrm{R}$ and $\mathrm{D}$ exercises.

\section{Conceptual Framework \& Hypothesis Development}

\section{Characteristics of R\&D culture}

Organizational culture is a lot of shared qualities, convictions and standards that characterize the right method for getting things done inside the association. The accompanying qualities are also significant for improving scholarly R and D execution. One of them is of vital importance i-e empowering Risk-taking (Magee, Leong et al. 2012). The presumption that hazard can be expected as long as the hazard doesn't harm the association doesn't urge scholastic analysts to attempt new thoughts (Filipczak 1997). Universities must urge their academicians to start look into work that includes a specific level of hazard, and simultaneously, universities must be set up to acknowledge disappointment. For instance, when university straightforwardly finance certain occupations that are important because of potential rewards, for example, protected innovation and information overflow, regardless of whether the likelihood of accomplishment is little, they energize hazard taking. Furthermore, scholastic scientists can likewise be urged to embrace 
hazardous $\mathrm{R}$ and $\mathrm{D}$ by setting up $\mathrm{R}$ and $\mathrm{D}$ impetuses, for example, paying eminences from their developments (Debackere and Veugelers 2005).

The next important factor is teamwork (Judge, Fryxell et al. 1997). At the point where individuals regard and see one another, share their shared objectives and impart adequately, collaboration is improved. When directing innovative work exercises in Universities, teachers and staff need to gauge different undertakings, to lead inquire about ventures, compose recommendations and acquire investigate financing.. To be fruitful, these exercises must be done inside the exploration group. In spite of the fact that it is, for the most part, accepted that singular rivalry will win in the scholarly world, (Berber and Kurul 2009) found that the undeniable pattern of cooperation and supporting aggregate scholastic work will in general drive R and D profitability.

The third significant factor is autonomy (Tushman and Nadler 1986). Malaysian's Tenth Plan (Unit 2010) sees that self-administration is key to invigorate university development and incredible $\mathrm{R}$ and $\mathrm{D}$. The arrangement expects colleges to have more noteworthy self-rule so they can freely allot scholastic and $\mathrm{R}$ and $\mathrm{D}$ reserves and decide need financing territories. Draw in and hold the opportunity of the best instructors through serious pay rates; and accept more noteworthy accountability and responsibility for university choices, including $\mathrm{R}$ and $\mathrm{D}$ vital course, needs and asset distribution. Inside explicit zones of R and $\mathrm{D}$ exercises, more noteworthy self-sufficiency permits the task group to figure nearby positive reaction gauges and empower obligation. At the point when scientists are permitted to seek after new thoughts and dispense fundamental assets, self-rule can likewise be upgraded. As such, the chance to create advancement $\mathrm{R}$ and D ought to be endowed to an R and D group that works like a free startup (Tellis and Golder 1996)

The fourth vital factor is tolerating errors and celebrating success. Misusing decides if individuals are eager to take creative activities (Martins and Terblanche 2003). Slip-ups can be disregarded, conceal, used to rebuff somebody, or then again can be treated as a learning opportunity (Brodtrick 1997). Whenever dependent on the investigation, the permitted blunders will give chances to keep up learning (Tushman and Nadler 1986). For the individuals who come up short, they should keep on recieving help. Fruitful associations, reward and achievement, recognizing disappointment by giving chances, to examine outcomes, gain from learning and finally celebrating is important in developing R \& D culture.

The fifth important factor is employee participation (Lawler III 1986). Cooperation implies pushing authority, dynamic obligation and information to the most decreased level of the affiliation. A concentrated association may turn into a significant deterrent to the reception of R and D (Wan, Ong et al. 2000). (Ayers, Gordon et al. 2001) propose that dynamic authority is important but facilitation to colleagues by bringing them on board is more vital.

The sixth factor is knowledge sharing. Workers must be urged to share information to make innovative work effective(Tushman and Nadler 1986). To make an information-sharing condition in a scholastic situation, it is essential to permit new plans to be proposed without quickly deciding their accuracy (Jain, Jain et al. 1997). Information sharing can be effectively done in direct contact, for example, in everyday conversations in the specialist 's research center, and when they go to the lab of an accomplice or customer (Lyons 2012). University need to give normal offices, for example, cafés, meeting rooms, and these assets should focuses on the goal that individuals can meet voluntarily and this will normally lead to information sharing.

The seventh factor is open communication or open correspondence. Open correspondence updates understanding and motivation just as signs laborers that they are trusted and that there is a common duty between the association and representatives (Judge, Fryxell et al. 1997); (Tushman and Nadler 1986). (Ahmed 1998) found that inventive associations have an announcing structure, which makes it feasible for workers to enter more elevated levels through numerous channels. The opportunity of detailing permits associations to pick thoughts, which are generally shortened during the ordinary screening process. Open 
correspondence isn't just vertical yet in addition level - between various divisions or distinctive research regions. The dynamic level correspondence stream makes open doors for inside information move and improves the college's absorptive limit (Daghfous 2004). Better interior correspondence can likewise upgrade social incorporation systems, consequently decreasing hindrances to data sharing, and improving the proficiency of digestion and change capacities (Van Den Bosch, Volberda et al. 1999).

The eighth factor is customer orientation. Presently, we are seeing an ever-increasing number of Universities move from the customary job of teaching students to a progressively unique job, along the lines of creating and commercializing research results (Berman 2011).For Universities to prevail in commercialization, they should comprehend the necessities of the market. The test here is that the exploration consequences of universities may get obsolete, which implies that the market and client base may not yet exist, or the market may not understand the advantages of new research when the research are acknowledged (Sturm and Parida 2012) Subsequently, to make scholarly research ventures creative and attractive research, universities should key structure key with the requirements of the market and clients (Rothaermel and Deeds 2006) .Basically, a client/showcase based authoritative culture will most viably make the vital conduct and make a higher incentive for universities (Von Hippel, Thomke et al. 1999).

The ninth factor is the importance of social networks. Malysians's Tenth five year Plan (Unit 2010) further expressed that one of the key approaches to fortify Universities innovative work (particularly in rising advances) is to direct procedures with global research foundations, the private segment and worldwide research organizations Cooperation. By building up contacts with associates in the business, scholastic researchers will have the option to trade information and mastery with their particular research fields. (Fukugawa 2013) found that cooperation among colleges and modern research can improve the aptitudes and capacities that $\mathrm{R}$ and $\mathrm{D}$ work force of little innovation organizations gain from outer information assets (ie University scientists or researchers). Presently, the same number of Universities are looking for new wellsprings of salary from the commercialization of advancement and innovations, coordinated effort and system associations with outside gatherings are additionally significant. (Severson 2004) found that this association has created a noteworthy rundown of inventive items, persuading that essential research in universities that help mechanical development exercises can help keep up their intensity. To begin building informal organizations, Universities need to urge specialists to take an interest in gatherings and expert affiliations. Become a staff individual from the expert affiliation office or serve on the diary article board.

\section{Transformational Leadership And Research \& Development Culture}

Usually, authoritative culture is formed by Organizational Leaders (Sarros, Gray et al. 2002). In any R and $\mathrm{D}$ association in the scholarly world, Leaders can build up a workplace that empowers imagination and advancement (Amabile, Schatzel et al. 2004). The transformational Leadership style is viewed as a significant factor supporting R and D and advancement (Nemanich and Vera 2009). (Bass and Avolio 2004, Rowold 2005) characterizes transformative administration as a powerful procedure in which pioneers change their supporters 'attention to significant things and permit them to see openings and open doors for themselves. Transformational pioneers are forceful and convince supporters to work more earnestly for more prominent potential and accomplishment.

Transformational Leadership has four angles, in particular: romanticized impact; inspiration, scholarly incitement; and individual contemplations (Bass and Avolio 2004). Perfect impact depicts pioneers as regarded and trusted by supporters. Researchers need to relate to leaders and consider them to be good examples. Such a leader consistently places the requirements of supporters above that person. Leader likewise share hazard with researchers. Rousing inspirations portray pioneers who spur everyone around them by giving importance and difficulties to the supporters 'work. Pioneers additionally urge researchers to consider appealing future states, along these lines moving individual and cooperation. Scholarly inspiration implies that pioneers challenge suspicions and take care of issues in new manners, along these lines moving their supporters' imaginative soul and effectively contributing thoughts. Supporters won't be 
openly censured for committing errors. Individual thought implies that the pioneer goes about as a tutor to concentrate on the individual 's requirement for accomplishment. Such pioneers give new learning chances in a steady environment by perceiving diverse individual needs and wants.

\section{Transformational Leadership \& Risk-Taking}

In $\mathrm{R}$ and $\mathrm{D}$, there are hazards in opening up new regions and there is no assurance of positive returns. Be that as it may, for R and D to have an upper hand, associations must guarantee that workers are urged to face challenges. Leader's eagerness to face challenges and commit errors might be the initial phase in the advancement procedure (Aragón-Correa, García-Morales et al. 2007). Transformational leaders can encourage individuals to inspect old issues from various points and dispose of business as usual, along these lines mentally motivating individuals to embrace an exploratory reasoning procedure (Sosik 1997). As the exploratory considering workers is imbued, it turns into the core value of increasingly imaginative experimentation and a courageous soul (Scott and Bruce 1994). Subsequently, we deduce that:

$\mathbf{H}_{1}$ : Transformational leadership has a positive impact on risk-taking.

\section{Transformational Leadership And Teamwork/ Group Diversity}

Like the business, scholastic $\mathrm{R}$ and $\mathrm{D}$ additionally includes numerous controls, inside and out. The Transformational Leadership is proper when the University means to give direction, vitality and attachment to people with various information and capacities (Tushman and Nadler 1986). Leaders can improve group union by filling in as the primary reference point. Leaders can urge individuals to acknowledge conflicting perspectives, prompting solidarity (Piper, Marrache et al. 1983). Adherents will adjust their inclinations to the aggregate interests and strategize the group (Piper, Marrache et al. 1983). As of late, (Zhang, Cao et al. 2011) upheld transformative Leadership by improving group execution by urging groups to receive cooperatives as opposed to serious peace promotion strategies. Accordingly, we propose a subsequent theory:

$\mathbf{H}_{2}$ : Transformational leadership has a positive impact on teamwork/group diversity.

\section{Transformational Leadership And Tolerance Of Mistakes/Celebrating Success}

Since $\mathrm{R}$ and $\mathrm{D}$ is an exploratory procedure, the outcomes are questionable. A mistake will happen. Transformational leaders can develop a culture that urges individuals to attempt various techniques without stressing over being rebuffed basically in light of the fact that the outcomes are negative (Amabile, Conti et al. 1996, Amabile, Schatzel et al. 2004). It has been discovered that empowering experimentation, enduring mistakes, and empowering ceaseless learning are among the components that help advancement (Martín-de Castro, López-Sáez et al. 2011) In this way, we suggest:

$\mathbf{H}_{3}$ : Transformational leadership has a positive impact on tolerance of mistakes and celebrating success.

\section{Transformational Leadership And Knowledge Sharing}

An $\mathrm{R}$ and $\mathrm{D}$ development work, the age and utilization of information. To exploit individuals' implied information, University VCs (Vice Chancellors), Deans and Head of Departments need to develop a culture of information sharing. Transformational administration is a factor that can animate information sharing (Jury, Bordia et al. 2005); (Nonaka and Takeuchi 1995). As Leader advance the quest for new chances, worker duties will increment and their insight sharing will unavoidably prosper (Avolio, Bass et al. 1999). In this way, we suggest:

$\mathbf{H}_{4}$ : Transformational leadership has a positive impact on knowledge sharing. 


\section{Transformational Leadership And Autonomy}

Autonomy implies that an individual can unreservedly conclude acceptable behavior. At the point when individuals can control how to finish a given undertaking, they will deliver increasingly innovative work (Amabile et al., 1996). For instance, in Universities, when Budget approved, the Vice Chancellors ought to conclude how to utilize the best techniques for $\mathrm{R}$ and $\mathrm{D}$ exercises, as suitable. Individuals' attention to expanded self-sufficiency can likewise be molded by scholarly incitement, in other words, senior University Leaders will welcome individuals to make different recommendations to improve their presentation. Besides, by directing customized pioneers, adherents can see more self-governance and input in their work (Piccolo and Colquitt 2006) Researchers accept that more noteworthy independence is an inner inspiration that eventually prompts higher profitability and employment fulfillment (Kuo, Ho et al. 2010), In this way, the fifth Hypothesis is

$\mathbf{H}_{5}$ : Transformational leadership has a positive impact on autonomy.

\section{Transformational Leadership And Employee Participation}

Transformational Leaderships gives more consideration to aggregate dynamic, shared objectives and capacity improvement, which is the embodiment of worker cooperation (Aragón-Correa, García-Morales et al. 2007)-. Worker cooperation is, when work environment permit researchers to apply a specific impact on their work and working conditions(Markey and Hodgkinson 2003). For the management, the researcher can expand efficiency, financial results, and compelling hierarchical change(Walters and Frick 2000). Researchers can all the more likely mastermind work and take care of issues (Masi and Cooke 2000). Higher management support can bring more prominent self-governance, work fulfilment, regard and quality. Appelbaum, and so on, 2000; (Preuss and Lautsch 2002). In this way, the 6th hypothesis that is

$\mathbf{H}_{\mathbf{6}}$ : Transformational leadership has a positive impact on employee participation.

\section{Transformational Leadership And Open Communication}

To exploit inventive thoughts, the University leaders must guarantee that, data streams unreservedly inside the organization. Researchers ought to be furnished with data about hierarchical exercises and bearings, and they should be permitted to convey important plans to the leadership (Rodwell, Kienzle et al. 1998). Transformational Leadership has a solid enthusiasm for correspondence culture. Pioneers with perfect impact need to discuss an unmistakable authoritative vision with all representatives (Aragón-Correa, García-Morales et al. 2007). Also, Leaders with customized thought will concentrate on representative issues; give input and welcome proposals from one another (Birasnav, Rangnekar et al. 2011). Along with these lines, the seventh hypothesis that is:

$\mathbf{H}_{7}$ : Transformational leadership has a positive impact on open communication.

\section{Transformational Leadership And Customer Orientation}

As Universities popularize $\mathrm{R}$ and $\mathrm{D}$ results, they have to stay touchy to advertise changes. So as not to pass up on any chance. To look after responsiveness, Universities must comprehend showcase needs, have the better most recent innovation, and utilize the innovation to develop (García-Morales, Jiménez-Barrionuevo et al. 2012). Transformational leaders need to control Universities since they are inventive, and they will in general backer development arranged approaches to adjust to advertise changes (Su-Tuan 2011). Additionally transformative Leadership assumes a significant job in accomplishing showcasing brand esteem (O'Cass, Wallace et al. 2011). Along with these lines, the eighth hypothesis that is

$\mathbf{H}_{8}$ : Transformational leadership has a positive impact on customer orientation. 


\section{Transformational Leadership and Social Networks}

The University endeavors to propel the boondocks of information and produce advancement revelations. Leaders ought to furnish scientists with approaches to set up contact with looks inside and outside the university. By going about as guides, Leaders can cause individuals to see one another, facilitate endeavors, manufacture duties and create extended informal organizations (Day 2000). Leaders can likewise empower new, non-excess associations with others inside and outside the association (Bouty 2000). Along these lines, we suggest the ninth theory

$\mathbf{H}_{\mathbf{9}}$ : Transformational leadership has a positive impact on social networks.

\section{Research Methodology}

The hypothetical system of this exam is the author's expansion of the work in 2005 and 2010 respectively. (Asmawi and Mohan 2005) Guiding exploratory background checks to distinguish the elements of hierarchical culture and R\&D activities among the $12 \mathrm{R} \& \mathrm{D}$ associations in Malaysia. All interviewees believe that administrative management is the most important factor affecting R\&D culture. In 2010, the author further studied the overall example of the hierarchical culture in three R\&D associations, which are government research organizations, private R\&D organizations, and universities. In view of these two earlier exams, this article hopes to increase the knowledge system by studying the links between transformational leadership and R\&D culture in Pakistani universities.

\section{Measures for Hypothesis testing}

The estimates of the nine categories of R\&D cultural factors are adapted from the author (Asmawi and Mohan 2010) Study where most things first evolved. Part of the estimation is adapted from: (Cabrales, Medina et al. 2008) (Cabrales, Medina et al. 2008)); (Denison and Neale 1996); (Hattori and Wycoff 2004); and (Prajogo and Ahmed 2006). Respondents provided their opinions on a five-point Likert scale from (1)completely disagree to (5)-completely agree. Use the Multi-Factor Leadership Questionnaire (MLQ) to estimate transformational leadership plans (Avolio, Bass et al. 1999). The survey consists of 20 items, which are evaluated on a five-point Likert type scale (from (1)-no (5)-regular) (if not general). MLQ questions were used to describe the management style of the leaders of the six interviewed universities. The reliability quality of R\&D cultural factors was tested using Cronbach's alpha reliability test. Eight of the nine variable categories exceed the accepted constant mass limit of 0.60 (Hair, Black et al. 2009) shown in Table $1 \& 2$.

Table 1: Reliability of Measures

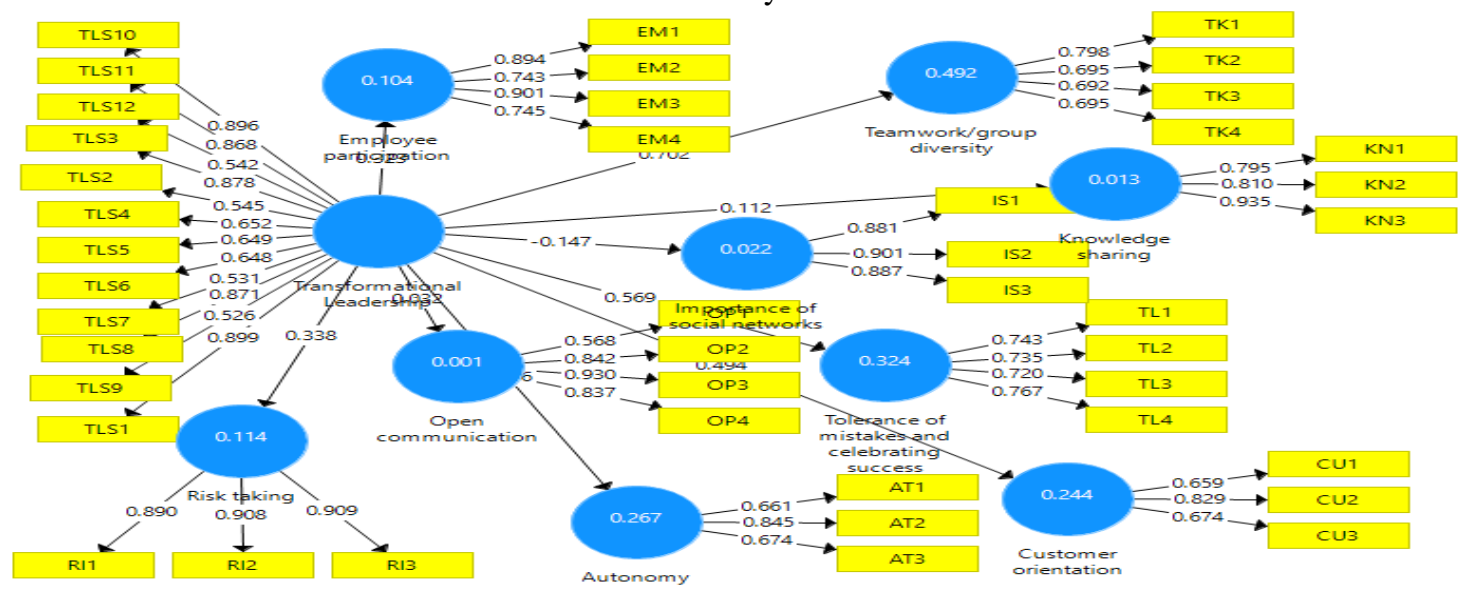


Table 2: Cronbach's alpha reliability test

\begin{tabular}{|l|c|}
\hline & Cronbach's Alpha \\
\hline Autonomy & 0.701 \\
\hline Customer orientation & 0.718 \\
\hline Employee participation & 0.848 \\
\hline Importance of social networks & 0.869 \\
\hline Knowledge sharing & 0.818 \\
\hline Open communication & 0.876 \\
\hline Risk taking & 0.886 \\
\hline Teamwork/group diversity & 0.743 \\
\hline Tolerance of mistakes and celebrating success & 0.732 \\
\hline Transformational Leadership & 0.911 \\
\hline
\end{tabular}

\section{Sampling procedure}

Purposeful sampling was used in this study. The sample is taken from the top ten Pakistani universities ranked by the Higher Education Commission of Pakistan. This research survey was conducted on 2500 absolute respondents from universities. A follow-up message was sent to urge respondents to be interested in the survey. In the end, 650 responses were obtained, $26 \%$ of which have been completed.

Table 3: Frequency Statistics

\begin{tabular}{|l|c|c|}
\hline \multicolumn{2}{|c|}{ Freq } & $\%$ \\
\hline Gender & 380 & 0.604134 \\
\hline Male & 249 & 0.395866 \\
\hline Female & 629 & \\
\hline Total & \multicolumn{2}{|l|}{} \\
\hline Education & 210 & 0.333863 \\
\hline Bachlor & 309 & 0.491256 \\
\hline MS/Mphil & 110 & 0.174881 \\
\hline PhD & 629 & \\
\hline Total & \multicolumn{2}{|l|}{} \\
\hline Universities & 85 & 0.135135 \\
\hline NUST & 101 & 0.160572 \\
\hline International Islamic Universities & 125 & 0.198728 \\
\hline Bahria University & 108 & 0.171701 \\
\hline Air University & 130 & 0.206677 \\
\hline Quaid e Azam University & 80 & 0.127186 \\
\hline National Defense University & 629 & 0.357711 \\
\hline \multicolumn{2}{|l|}{} \\
\hline Faculty & 225 & 0.213037 \\
\hline Business & 134 & 0.174881 \\
\hline Social Science & 110 & 0.130366 \\
\hline Engineering & 82 & 0.085851 \\
\hline Computer Science & 54 & 0.038156 \\
\hline Psychology & 24 & \\
\hline Others & 629 & \\
\hline Total & \multicolumn{2}{|l|}{} \\
\hline
\end{tabular}


After eliminating $0.04 \%$ of the poll answers in any case, the remaining 629 samples were used for the survey. Due to the low overall response rate, people realize that these responses will no longer be commissioned and generalizable. In any case, the results still prove the overall situation of these six universities. There is no doubt that using a large number of Pakistani universities for further examinations is crucial. Table 3 shows the fragment quality of the samples.

\section{Patterns Of R\&D Culture In Pakistani Universities}

This area examines the discoveries on the patterns of R\&D culture in Pakistani Universities. In Table 4 For 'Transformational Leadership', respondents from all universities concurred that they focus on transformational leadership. As 'Risk Taking' all universities respondents agreed that universities allowed to take risk. As 'Team Work' all universities are already focusing on team work. All universities provide 'Autonomy' to their employees. All respondents agreed that universities give tolerance to their employee. All respondents agreed that employee participation is encouraged. Open communication value slightly agreed from all respondents. Knowledge sharing value is not high just slightly agreed or neutral. Value of information sharing is agreed among all respondents. Respondents also agreed that customer orientation is also focused.

Table 4. Patterns of R \& D Culture

\begin{tabular}{|l|c|c|}
\hline & Mean & Standard Deviation \\
\hline TLS1 & 3.784 & 0.964 \\
\hline TLS2 & 3.882 & 0.937 \\
\hline TLS3 & 3.738 & 1.004 \\
\hline TLS4 & 3.963 & 0.924 \\
\hline TLS5 & 3.963 & 0.926 \\
\hline TLS6 & 3.965 & 0.921 \\
\hline TLS7 & 3.769 & 0.986 \\
\hline TLS8 & 3.747 & 0.985 \\
\hline TLS9 & 3.806 & 1.025 \\
\hline TLS10 & 3.785 & 0.972 \\
\hline TLS11 & 3.789 & 0.963 \\
\hline TLS12 & 3.994 & 0.877 \\
\hline Transformational Leadership & 3.84875 & 0.957 \\
\hline RI1 & 3.862 & 1.13 \\
\hline RI2 & 3.895 & 1.137 \\
\hline RI3 & 3.901 & 1.126 \\
\hline Risk taking & 3.886 & 1.1315 \\
\hline TK1 & 3.874 & 0.898 \\
\hline TK2 & 3.997 & 0.831 \\
\hline TK3 & 3.997 & 0.823 \\
\hline TK4 & 3.925 & 0.923 \\
\hline TK5 & 4.056 & 0.804 \\
\hline Teamwork & 3.973 & 0.859 \\
\hline AT1 & 4.102 & 0.839 \\
\hline AT2 & 3.844 & 0.922 \\
\hline AT3 & 4.11 & 0.864 \\
\hline Autonomy & 4.018667 & 0.875 \\
\hline TL1 & 3.99 & 0.846 \\
\hline TL2 & 3.924 & 0.951 \\
\hline TL3 & 3.949 & 0.934 \\
\hline TL4 & 4.041 & 0.85 \\
\hline
\end{tabular}




\begin{tabular}{|l|c|c|} 
Tolereance & 3.976 & 0.89525 \\
\hline EM1 & 3.782 & 1.041 \\
\hline EM2 & 3.703 & 1.038 \\
\hline EM3 & 3.773 & 1.043 \\
\hline EM4 & 3.682 & 1.034 \\
\hline Employee participation & 3.735 & 1.039 \\
\hline OP1 & 3.607 & 1.208 \\
\hline OP2 & 3.69 & 1.125 \\
\hline OP3 & 3.657 & 1.144 \\
\hline OP4 & 3.738 & 1.09 \\
\hline Open Communication & 3.673 & 1.14175 \\
\hline KN1 & 3.447 & 1.217 \\
\hline KN2 & 3.512 & 1.206 \\
\hline KN3 & 3.531 & 1.201 \\
\hline Knowledge Sharing & 3.496667 & 1.208 \\
\hline IS1 & 3.757 & 1.092 \\
\hline IS2 & 3.722 & 1.127 \\
\hline IS3 & 3.739 & 1.147 \\
\hline Information Sharing & 3.739333 & 1.122 \\
\hline CU1 & 4.096 & 0.832 \\
\hline CU2 & 3.808 & 0.95 \\
\hline CU3 & 4.092 & 0.889 \\
\hline Customer Orientation & 3.998667 & 0.890333333 \\
\hline
\end{tabular}

Table 5: Reliability and Validity Test

\begin{tabular}{|l|c|c|c|}
\hline & rho_A & $\begin{array}{c}\text { Composite } \\
\text { Reliability }\end{array}$ & AVE \\
\hline Autonomy & 0.711 & 0.773 & 0.535 \\
\hline Customer orientation & 0.721 & 0.766 & 0.525 \\
\hline Employee participation & 0.884 & 0.894 & 0.680 \\
\hline Importance of social networks & 0.882 & 0.919 & 0.791 \\
\hline Knowledge sharing & 1.039 & 0.885 & 0.720 \\
\hline Open communication & 0.707 & 0.878 & 0.649 \\
\hline Risk taking & 0.886 & 0.929 & 0.814 \\
\hline Teamwork/group diversity & 0.846 & 0.812 & 0.520 \\
\hline Tolerance of mistakes and celebrating success & 0.740 & 0.830 & 0.550 \\
\hline Transformational Leadership & 0.919 & 0.927 & 0.526 \\
\hline
\end{tabular}

In above picture all factor loading values (table 5) are greater than above 0.5 and no value is above 0.95

\section{Construct Reliability and Validity:}

To check the Construct Validity and Reliability value of rho_A value should be above 0.7 and AVE value should be above 0.5. Above table shows that the Construct are reliable and valid.

\section{Relationship Between Transformational Leadership And R\&D Culture}

Table 6 explains the descriptive statistics and correlations between R\&D culture and transformational leadership variables. A high degree of correlation was found between R\&D cultural variables -0.147 to 
0.702. The results in Table 6 show that, except for the importance of social networks, all variables are positively correlated with transformational leadership.

Table 6: Correlation between R \& D Culture

\begin{tabular}{|c|c|c|c|c|c|c|c|c|c|c|}
\hline & Autonomy & $\begin{array}{c}\text { Customer } \\
\text { orientation }\end{array}$ & $\begin{array}{l}\text { Employee } \\
\text { participati } \\
\text { on }\end{array}$ & $\begin{array}{l}\text { Importance } \\
\text { of social } \\
\text { networks }\end{array}$ & $\begin{array}{l}\text { Knowledge } \\
\text { sharing }\end{array}$ & $\begin{array}{c}\text { Open } \\
\text { communication }\end{array}$ & $\begin{array}{l}\text { Risk } \\
\text { taking }\end{array}$ & $\begin{array}{l}\text { Teamwork/gr } \\
\text { oup diversity }\end{array}$ & $\begin{array}{l}\text { Tolerance } \\
\text { of } \\
\text { mistakes } \\
\text { and } \\
\text { celebrating } \\
\text { success }\end{array}$ & $\begin{array}{c}\text { Transformational } \\
\text { Leadership }\end{array}$ \\
\hline Autonomy & 1.000 & 0.978 & 0.146 & -0.103 & 0.009 & 0.020 & 0.326 & 0.505 & 0.486 & 0.516 \\
\hline $\begin{array}{l}\text { Customer } \\
\text { orientation }\end{array}$ & 0.978 & 1.000 & 0.132 & -0.102 & 0.015 & 0.012 & 0.301 & 0.483 & 0.467 & 0.494 \\
\hline $\begin{array}{l}\text { Employee } \\
\text { participation } \\
\end{array}$ & 0.146 & 0.132 & 1.000 & -0.084 & 0.017 & 0.085 & 0.215 & 0.282 & 0.399 & 0.323 \\
\hline $\begin{array}{l}\text { Importance of } \\
\text { social networks }\end{array}$ & -0.103 & -0.102 & -0.084 & 1.000 & -0.028 & 0.088 & 0.047 & -0.173 & -0.088 & -0.147 \\
\hline $\begin{array}{l}\text { Knowledge } \\
\text { sharing }\end{array}$ & 0.009 & 0.015 & 0.017 & -0.028 & 1.000 & 0.024 & 0.106 & 0.051 & 0.109 & 0.112 \\
\hline $\begin{array}{l}\text { Open } \\
\text { communication }\end{array}$ & 0.020 & 0.012 & 0.085 & 0.088 & 0.024 & 1.000 & 0.139 & 0.062 & 0.077 & 0.032 \\
\hline Risk taking & 0.326 & 0.301 & 0.215 & 0.047 & 0.106 & 0.139 & 1.000 & 0.328 & 0.306 & 0.338 \\
\hline $\begin{array}{l}\text { Teamwork/group } \\
\text { diversity }\end{array}$ & 0.505 & 0.483 & 0.282 & -0.173 & 0.051 & 0.062 & 0.328 & 1.000 & 0.504 & 0.702 \\
\hline $\begin{array}{lr}\begin{array}{l}\text { Tolerance } \\
\text { mistakes }\end{array} \\
\text { celebrating } \\
\text { success }\end{array}$ & 0.486 & 0.467 & 0.399 & -0.088 & 0.109 & 0.077 & 0.306 & 0.504 & 1.000 & 0.569 \\
\hline $\begin{array}{l}\text { Transformational } \\
\text { Leadership }\end{array}$ & 0.516 & 0.494 & 0.323 & -0.147 & 0.112 & 0.032 & 0.338 & 0.702 & 0.569 & 1.000 \\
\hline
\end{tabular}

For hypothesis testing regression analysis were used. Results are shown in table 7 and 8 . Table 7 results shows that Importance of Social Network, Knowledge Sharing and Open Communication have very less variation due to Independent Variable i.e Transformational Leadership. Even Open Communication has minus variation as per Adjusted R Squared value.

Table 7: Hypothesis Testing

\begin{tabular}{|l|c|c|}
\hline & R Square & R Square Adjusted \\
\hline Autonomy & 0.267 & 0.266 \\
\hline Customer orientation & 0.244 & 0.243 \\
\hline Employee participation & 0.104 & 0.103 \\
\hline Importance of social networks & 0.022 & 0.020 \\
\hline Knowledge sharing & 0.013 & 0.011 \\
\hline Open communication & 0.001 & -0.001 \\
\hline Risk taking & 0.114 & 0.113 \\
\hline Teamwork/group diversity & 0.492 & 0.491 \\
\hline Tolerance of mistakes and celebrating success & 0.324 & 0.323 \\
\hline
\end{tabular}


Table 8: Regression Analysis

\begin{tabular}{|c|c|c|c|c|c|c|c|}
\hline & Hypothesis & $\begin{array}{l}\text { Original } \\
\text { Sample } \\
\text { (O) }\end{array}$ & $\begin{array}{l}\text { Sample } \\
\text { Mean } \\
\text { (M) }\end{array}$ & $\begin{array}{l}\text { Standard } \\
\text { Deviation } \\
\text { (STDEV) }\end{array}$ & $\begin{array}{l}\text { T Statistics } \\
(|\mathrm{O} / \mathrm{STDEV}|)\end{array}$ & $\begin{array}{c}\mathrm{P} \\
\text { Values }\end{array}$ & Status \\
\hline $\begin{array}{l}\text { Transformational } \\
\text { Leadership } \\
\text { Autonomy }\end{array}$ & H5 & 0.516 & 0.520 & 0.035 & 14.765 & 0.000 & Accepted \\
\hline $\begin{array}{l}\text { Transformational } \\
\text { Leadership -> Customer } \\
\text { orientation }\end{array}$ & H8 & 0.494 & 0.498 & 0.036 & 13.720 & 0.000 & Accepted \\
\hline $\begin{array}{l}\text { Transformational } \\
\text { Leadership -> Employee } \\
\text { participation }\end{array}$ & H6 & 0.323 & 0.323 & 0.040 & 8.148 & 0.000 & Accepted \\
\hline Transformational & H9 & & & & & & \\
\hline $\begin{array}{l}\text { Leadership } \\
\text { Importance of } \\
\text { networks }\end{array}$ & & -0.147 & -0.152 & 0.038 & 3.860 & 0.000 & Rejected \\
\hline $\begin{array}{l}\text { Transformational } \\
\text { Leadership } \\
\text { Knowledge sharing }\end{array}$ & $\mathrm{H} 4$ & 0.112 & 0.119 & 0.040 & 2.828 & 0.005 & Accepted \\
\hline $\begin{array}{l}\text { Transformational } \\
\text { Leadership -> Open } \\
\text { communication }\end{array}$ & $\mathrm{H} 7$ & 0.032 & 0.026 & 0.065 & 0.491 & 0.623 & Rejected \\
\hline $\begin{array}{l}\text { Transformational } \\
\text { Leadership } \quad \rightarrow \quad \text { Risk } \\
\text { taking }\end{array}$ & $\mathrm{H} 1$ & 0.338 & 0.340 & 0.042 & 8.082 & 0.000 & Accepted \\
\hline $\begin{array}{l}\text { Transformational } \\
\text { Leadership } \\
\text { Teamwork/group } \\
\text { diversity }\end{array}$ & $\mathrm{H} 2$ & 0.702 & 0.706 & 0.027 & 26.319 & 0.000 & Accepted \\
\hline $\begin{array}{l}\text { Transformational } \\
\text { Leadership }->\text { Tolerance } \\
\text { of mistakes and } \\
\text { celebrating success }\end{array}$ & $\mathrm{H} 3$ & 0.569 & 0.571 & 0.035 & 16.132 & 0.000 & Accepted \\
\hline
\end{tabular}

All hypothesis are statistically accepted except $\mathrm{H}_{7}$ and $\mathrm{H}_{9}$.

\section{Discussion and Conclusion}

The regression analysis results show that transformational leadership is positively related to research culture (Aragón-Correa, García-Morales et al. 2007) and (Sosik 1997) have stable results. These surveys found that when analyst leaders continue to urge them to investigate prospects beyond their comfort level and look at problems from all angles, they can remain innovative. As long as leaders provide the necessary assets and learning opportunities, they can build a beneficial R\&D culture.

Steady with the examinations by (Tushman and Nadler 1986), (Sosik 1997) and (Zhang, Cao et al. 2011), groundbreaking authority is positively connected to cooperation and gathering decent variety. The capacity to expand bunch attachment in an R\&D venture is undoubtedly a huge test. Analysts are the individuals who are profoundly taught, have the high inclination and are exceptionally self-ruling. This special arrangement of individuals positively requires a leader who can cause them to acknowledge their differences and endeavor towards Leadership expectations. Recognizing that not all senior management / administration/ Vice Chancellors are groundbreaking, the university ought to give learning chances to extend leaders to gain groundbreaking practices. To underscore the significance of groundbreaking practices, the Universities top / senior administration must 'walk the discussion' by turning into the good examples of transformational leaders themselves. 
In addition, it is found that transformational leaders are more suitable for exploratory R\&D culture. These leaders urge individuals to exceed their limits and confirm to individuals that confusion and disappointment are an integral part of the development cycle. Subordinates will not be rejected or publicly condemned for making mistakes. More importantly, these pioneers paid more attention to how much their researchers gained from these mistakes and continued to improve themselves. The university administration must give the right signals by holding training and mentoring meetings, on-campus courses, and lectures to allow scientists to share best practices and learned exercises. Therefore, experts can benefit each other without having to redo similar mistakes, which is expensive for the organization.

Groundbreaking LEADERS effectively look for novel thoughts and innovative arrangements from team. This characteristic turns into the stimulus for an information sharing society in universities. Readiness to share information can be sustained just when researchers have common trust and comprehension. Leaders, through their glorified impact, set the model by disguising information sharing. As these leaders are being regarded and trusted by their researchers, adherents will definitely copy this information sharing practice.

As referenced above, researchers are profoundly self-ruling, characteristically propelled and are specialists in their exploration specialization. Through coaching (Piccolo and Colquitt 2006), groundbreaking leaders can support more prominent self-governance and give criticism on scientists' positions. With more prominent autonomy, individuals have more authority over their activity which will prompt higher employment fulfillment (Kuo, Ho et al. 2010).

Research and development measure is unsure and difficult. As a rule, the specialist would lose center around their employment. Thusly to keep up their inspiration, analysts should have the option to envision the master plan of the R\&D endeavors. To do this, leaders need to get their kin to partake in outlining the R\&D strategy of the universities.

In this survey, transformational leaders were also identified as openly communicating because they were worried (Aragón-Correa, García-Morales et al. 2007). University leaders with far-reaching influence strive to establish a common vision throughout the organization. When this cycle occurs, leaders need to open themselves so that they can ask workers to draw conclusions and pay attention to their problems. Through this open letter, individuals will see the university adapt to them and think about their prosperity.

Groundbreaking leaders can emphatically contribute to more prominent informal organization (Bouty 2000); (Day 2000). Through tutoring, and utilizing on leaders' own system, individuals are urged to communicate with different gatherings outside the universities. This will prompt cross-preparation of thoughts from numerous contacts, for example, outside specialists, sellers, award suppliers, clients and even contenders.

It is intriguing to take note of that Pakistan as of now has a social component which is a key fixing in a R\&D culture. Pakistan is a multicultural country portrayed as an exceptionally collectivistic culture. The individuals customarily carry on in a mutual manner. They deal with one another like a family. This mutual conduct is likewise predominant in the Pakistani working environment. People normally bond into solid strong gatherings, supporting each other when the need emerges. Research and development directors in universities can use this incentive to upgrade cooperation in their ventures. Research and development exercises should be structured in a synergistic way so that toward the finish of the cycle, scientists are remunerated aggregately as opposed to independently. Also, common trust that is as of now profound established in the Pakistani culture can turn into a solid establishment for information sharing.

\section{Research Limitations}

Due to consistent quality issues, this inspection needs to deal with six estimates, which are recommended to have a negative impact on the $R \& D$ culture. These measures include situations where $R \& D$ activities are 
suffocated because individuals are not allowed to explore different ways of thinking beyond the scope of the exploration career. In an ideal R\&D culture, as long as there is mutual trust and cooperation, individuals will share ideas without hesitation. In any case, a culture that hinders R\&D is an individual. In this culture, when things get bad, individuals usually blame each other. Often, individuals will also act individually, because the benefits of reward providers are often overlooked by their choices, and they will not be educated by senior management about current university events and circumstances. For this reason, further exploration should be carried out to solve the reliability problems in these measures, as a key R\&D cultural factor.

Another shortcoming of this investigation is that it only revolves around the professional and business components that bear the risk. Since academic examinations are absolutely fundamental and exploratory, it is normal to allow experts to accept the dangers indicated by such investigations. Nevertheless, the different components of danger have also been explored academically, especially the subsidies for the dangers, and the tasks of the executives are given to the dangers. The R\&D activities of universities (open and private) are largely funded by HEC awards. Because the means of awarding awards depends to a large extent on economic strength and the focus of current administration, universities are faced with funding opportunities-the possibility of insufficient subsidies for R\&D activities. When the country's use of R\&D decreases, universities need to establish optional resource-raising fountains, such as mechanical rewards. For universities, expanding mechanical rewards for necessary exams is a test because private companies will quickly support R\&D projects that have proven business returns. Again, this is also a problem for universities, especially private universities, because they have a limited money-related buffer that can be allocated as internal R\&D subsidies. In this case, pioneering leaders must assume the responsibility of discovering imaginative methods to ensure that researchers have sufficient assets to carry out their own businesses.

Scholarly analysts are likewise confronted with nature of the executives hazards. It is recognized that specialists are specialists in their own field of examination. Nonetheless, overseeing R\&D ventures requires a different set of capabilities, for example, authoritative abilities, relational aptitudes and relational abilities.

The investigation tried to estimate connections between leadership and eight factors of R\&D culture. While all theories were factually upheld, it should be noted that the level of recognition also plays a role in shaing the opinion of the individuals who work for the universities. In spite of the impediments, the examination identifies the requirement for universities to connect more in transformational leadership. Past investigations have indicated that transformational leadership is fundamental in forming R\&D culture.

\section{References}

Abd Razak, D. (2009). "USM Apex University Status: Transforming higher education for a sustainable tomorrow." The Malaysian journal of medical sciences: MJMS 16(1): 1.

Aghion, P., et al. (2008). "Academic freedom, private-sector focus, and the process of innovation." The RAND Journal of Economics 39(3): 617-635.

Ahmed, P. K. (1998). "Culture and climate for innovation." European journal of innovation management.

Amabile, T. M., et al. (1996). "Assessing the work environment for creativity." Academy of management journal 39(5): 1154-1184.

Amabile, T. M., et al. (2004). "Leader behaviors and the work environment for creativity: Perceived leader support." The Leadership Quarterly 15(1): 5-32.

Aragón-Correa, J. A., et al. (2007). "Leadership and organizational learning's role on innovation and performance: Lessons from Spain." Industrial marketing management 36(3): 349-359.

Asmawi, A. and A. Mohan (2005). Identifying dimensions of organizational culture and their relationship with R\&D activities: A qualitative study in Malaysian R\&D organizations. Proceedings of the National Conference on Management of Technology and Technology Entrepreneurship (MOTTE), Johor Bahru, Malaysia. 
Asmawi, A. and A. Mohan (2010). Understanding patterns of organizational culture: A study in Malaysian R\&D institutions. 2010 IEEE International Conference on Management of Innovation \& Technology, IEEE.

Asmawi, A., et al. (2013). "Understanding transformational leadership and R\&D culture in Malaysian universities." Innovation 15(3): 287-304.

Avolio, B. J., et al. (1999). "Re-examining the components of transformational and transactional leadership using the Multifactor Leadership." Journal of occupational and organizational psychology 72(4): 441462.

Ayers, D. J., et al. (2001). "Integration and new product development success: The role of formal and informal controls." Journal of Applied Business Research (JABR) 17(2).

Bass, B. and B. Avolio (2004). "Multifactor leadership questionnaire-MLQ self-evaluation." Manual and sampler set (3rd ed.). Redwood City, CA: Mindgarden: 5-9.

Beerkens, E. (2010). "Global models for the national research university: adoption and adaptation in Indonesia and Malaysia." Globalisation, Societies and Education 8(3): 369-391.

Berber, R. and N. Kurul (2009). The Motivating factors for productivity in R\&D: Preliminary results of a survey in some engineering schools in Turkey. PICMET'09-2009 Portland International Conference on Management of Engineering \& Technology, IEEE.

Berman, E. P. (2011). Creating the market university: How academic science became an economic engine, Princeton University Press.

Berson, Y. and B. J. Avolio (2004). "Transformational leadership and the dissemination of organizational goals: A case study of a telecommunication firm." The Leadership Quarterly 15(5): 625-646.

Birasnav, M., et al. (2011). "Transformational leadership and human capital benefits: The role of knowledge management." Leadership \& Organization Development Journal.

Bouty, I. (2000). "Interpersonal and interaction influences on informal resource exchanges between R\&D researchers across organizational boundaries." Academy of management journal 43(1): 50-65.

Brodtrick, O. (1997). "Innovation as reconciliation of competing values." Optimum 27(2): 1-4.

Cabrales, Á. L., et al. (2008). "Managing functional diversity, risk taking and incentives for teams to achieve radical innovations." $R \& d$ Management $38(1): 35-50$.

Daghfous, A. (2004). "Absorptive capacity and the implementation of knowledge-intensive best practices." SAM Advanced Management Journal 69(2): 21.

Day, D. V. (2000). "Leadership development:: A review in context." The Leadership Quarterly 11(4): 581 613.

Debackere, K. and R. Veugelers (2005). "The role of academic technology transfer organizations in improving industry science links." Research policy 34(3): 321-342.

Denison, D. R. and W. Neale (1996). "Denison organizational culture survey." Ann Arbor, MI: Aviat.

Filipczak, B. (1997). "It Takes All Kinds: Creativity in the Work Force." Training 34(5): 32.

Fukugawa, N. (2013). "University spillovers into small technology-based firms: Channel, mechanism, and geography." The Journal of Technology Transfer 38(4): 415-431.

García-Morales, V. J., et al. (2012). "Transformational leadership influence on organizational performance through organizational learning and innovation." Journal of business research 65(7): 1040-1050.

Hair, J. F., et al. (2009). Análise multivariada de dados, Bookman editora.

Hattori, R. A. and J. Wycoff (2004). Innovation training, American Society for Training and Development.

Hunter, S. T., et al. (2007). "The typical leadership study: Assumptions, implications, and potential remedies." The Leadership Quarterly 18(5): 435-446.

Islamabad, P. (2013). "Government of Pakistan: Islamabad." Pakistan2013 [Google Scholar].

Jain, R. K., et al. (1997). Management of research and development organizations: managing the unmanageable, John Wiley \& Sons.

Judge, W. Q., et al. (1997). "The new task of R\&D management: creating goal-directed communities for innovation." California management review 39(3): 72-85.

Jury, A., et al. (2005). Transformational leadership within virtual teams: Examining the mediating influence of trust and role clarity for performance and knowledge sharing. B. Myers, Australian Journal of Psychology: The Abstracts of the 6th Australian Industrial and Organisational Psychology 
Conference. 6th Australian Industrial and Organizational Psychology Conference (30 June-3 July), Gold Coast, QLD.

Kuo, T. H., et al. (2010). "The factors influencing employees' attitudes in high-tech environment." Industrial Management \& Data Systems.

Lawler III, E. E. (1986). High-Involvement Management. Participative Strategies for Improving Organizational Performance, ERIC.

Lyons, J. W. (2012). Reflections on Over Fifty Years in Research and Development; Some Lessons Learned, National Defense Univ Washington Dc Center for Technology and National ....

Magee, C. L., et al. (2012). "Beyond R\&D: What design adds to a modern research university."

Markey, R. and A. Hodgkinson (2003). "How employment status genders access to employee participation in Australian workplaces." International Employment Relations Review 9(2): 111.

Martín-de Castro, G., et al. (2011). "Organizational factors to support knowledge management and innovation." Journal of knowledge management.

Martins, E. C. and F. Terblanche (2003). "Building organisational culture that stimulates creativity and innovation." European journal of innovation management.

Masi, R. J. and R. A. Cooke (2000). "Effects of transformational leadership on subordinate motivation, empowering norms, and organizational productivity." International Journal of Organizational Analysis 8(1): 16.

Moss, G. and K. Kubacki (2007). "Researchers in higher education: a neglected focus of study?" Journal of further and higher education 31(3): 297-310.

Nemanich, L. A. and D. Vera (2009). "Transformational leadership and ambidexterity in the context of an acquisition." The Leadership Quarterly 20(1): 19-33.

Nonaka, I. and H. Takeuchi (1995). The knowledge-creating company: How Japanese companies create the dynamics of innovation, Oxford university press.

O'Cass, A., et al. (2011). "The influence of culture and market orientation on services brands: insights from Irish banking and retail firms." Journal of Services Marketing.

Piccolo, R. F. and J. A. Colquitt (2006). "Transformational leadership and job behaviors: The mediating role of core job characteristics." Academy of management journal 49(2): 327-340.

Piper, W. E., et al. (1983). "Cohesion as a basic bond in groups." Human Relations 36(2): 93-108.

Prajogo, D. I. and P. K. Ahmed (2006). "Relationships between innovation stimulus, innovation capacity, and innovation performance." $R \& d$ Management 36(5): 499-515.

Preuss, G. and B. Lautsch (2002). "The effect of formal versus informal job security on employee involvement programs." Relations industrials/Industrial Relations 57(3): 517-541.

Rodwell, J. J., et al. (1998). "The relationship among work-related perceptions, employee attitudes, and employee performance: The integral role of communications." Human Resource Management: Published in Cooperation with the School of Business Administration, The University of Michigan and in alliance with the Society of Human Resources Management 37(3-4): 277-293.

Rothaermel, F. T. and D. L. Deeds (2006). "Alliance type, alliance experience and alliance management capability in high-technology ventures." Journal of business venturing 21(4): 429-460.

Rowold, J. (2005). "Multifactor leadership questionnaire." Psychometric properties of the German translation by Jens Rowold. Redwood City: Mind Garden.

Sarros, J. C., et al. (2002). "Leadership and its impact on organizational culture." International Journal of Business Studies 10(2).

Scott, S. G. and R. A. Bruce (1994). "Determinants of innovative behavior: A path model of individual innovation in the workplace." Academy of management journal 37(3): 580-607.

Severson, J. A. (2004). "Models of university-industry cooperation." Journal of Industry-AcademiaGovernment Collaboration 2: 1-6.

Sosik, J. J. (1997). "Effects of transformational leadership and anonymity on idea generation in computermediated groups." Group \& Organization Management 22(4): 460-487.

Sturm, D. and V. Parida (2012). "User-centred research and technology development: A study of a Swedish university project." International Journal of Business and Management Tomorrow 2(1). 
Su-Tuan, L. (2011). "Transformational Leadership: Leadership in Education." Educause. edu. According to the abstract, Created by Su-Tuan Lulee (WIDE) on March 13: 2011.

Tellis, G. J. and P. N. Golder (1996). "First to market, first to fail? Real causes of enduring market leadership." MIT Sloan management review 37(2): 65-75.

Tushman, M. and D. Nadler (1986). "Organizing for innovation." California management review 28(3): 7492.

Tynan, B. R. and D. L. Garbett (2007). "Negotiating the university research culture: Collaborative voices of new academics." Higher Education Research \& Development 26(4): 411-424.

Unit, E. P. (2010). "Tenth Malaysia Plan 2011-2015." Malaysia: Economic Planning Unit.

Van Den Bosch, F. A., et al. (1999). "Coevolution of firm absorptive capacity and knowledge environment: Organizational forms and combinative capabilities." Organization science 10(5): 551-568.

Von Hippel, E., et al. (1999). "Creating breakthroughs at 3M." Harvard Business Review 77: 47-57.

Walters, D. and K. Frick (2000). "Worker participation and the management of occupational health and safety: reinforcing or conflicting strategies." Systematic occupational health and safety management: perspectives on an international development 43: 66.

Wan, T. W., et al. (2000). The impact of firm characteristics on firm innovation. Proceedings of the 2000 IEEE International Conference on Management of Innovation and Technology. ICMIT 2000.'Management in the 21st Century'(Cat. No. 00EX457), IEEE.

Zhang, X. a., et al. (2011). "Linking transformational leadership and team performance: A conflict management approach." Journal of Management Studies 48(7): 1586-1611. 